\title{
CLINICAL AND IMMUNOLOGICAL STATUS OF CHILDREN WITH LYME DISEASE
}

\section{KLINICZNY I IMMUNOLOGICZNY STAN DZIECI Z BORELIOZĄ}

\author{
Svitlana Nykytyuk ${ }^{1(A, B, D)}$, Sergiy Klymnyuk ${ }^{2(C, D)}$ \\ ${ }^{1}$ Department of Children's Diseases and Pediatric Surgery, \\ Ivan Horbachevsky Ternopil National Medical University, Ternopil, Ukraine \\ ${ }^{2}$ Department of Microbiology, Virology and Immunology, \\ Ivan Horbachevsky Ternopil National Medical University, Ternopil, Ukraine
}

Authors' contribution Wkład autorów:

A. Study design/planning zaplanowanie badań

B. Data collection/entry zebranie danych

C. Data analysis/statistics dane - analiza i statystyki D. Data interpretation interpretacja danych E. Preparation of manuscript przygotowanie artykułu F. Literature analysis/search wyszukiwanie i analiza literatury G. Funds collection zebranie funduszy
Tables: 0

Figures: 0

References: 6

Submitted: 2021 Jul 20

Accepted: 2021 Aug 3

\section{Dear Editor,}

Lyme disease (LD) is a naturally occurring disease mainly caused by Borrelia burgdorferi. This problem has been of outstanding importance since 2017, as Western Ukraine, particularly the Ternopil region, is a territory endemic of Lyme borreliosis.

The insufficient consideration of the epidemiological history, the epidemic history, and the hereditary and allergic history of a patient leads to an erroneous diagnosis and possible mistakes in the treatment. Pediatric providers in the endemic regions, especially those working in hospitals, must be thus familiar with the clinical presentation and must have a high index of suspicion for LD in order to prevent mismanagement $[1,2]$.

Our research was devoted to the prognostic model for the functional recovery of patients with Lyme disease by combining the study of demographic indicators, the frequency of bites and the clinical and laboratory indicators. We described a clinical picture of LD (arthritis, ery thema migrans, neuropsyhical disorder) and the clinical features that distinguish it from other diseases (other forms based on the laboratory and instrumental methods of children's examination). This is important because of the polymorphism of symptoms and also due to the number of related factors (the accession of infections, the age of the patient, the premorbid diseases, the social situation, etc.) that are crucial in the chronization of the disease [3].

In our first study, a survey of 825 patients with a clinical suspicion of LD was conducted. In the second study, we carried out a laboratory analysis of 825 ticks and 139 blood samples from children that were bitten by a tick. Real-time Polymerase Chain Reaction (PCR) with the use of the Vector-Best production test systems was applied to detect the infected ticks and to evaluate the genotype of the pathogen. We determined DNA B. burgdorferi sensu lato (B. burgdorferi sensu stricto, B. afzelii, $B$. garinii), B. miyamotoi, $A$. phagocytophilum using real-time PCR to analyze the ticks and the blood of the patients. A two-stage study with the use of ELISA and immunoblot was carried out as well [4].

The real-time PCR test demonstrated that in the blood sample of 30 children B. burgdorferi was found in 2 children (6.6\%), A. phagocytophilum - in 2 children (6.6\%), B. miyamotoi - in 3 children (10.0\%), B. burgdorferi sl compatible with $A$. phagocytophilum and B. miyamotoi - in 1 child (3.3\%), B. miyamotoi and tick-borne encephalitis virus - in 1 child (3.3\%), tick-borne encephalitis virus - in 7 children (23\%). The simultaneous infection of ticks with several pathogens of transmissible bacteriosis may pose a high risk of developing a transmissible mixed infection in

Keywords: Lyme disease, ELISA, PCR, children

Słowa kluczowe: borelioza, ELISA, PCR, dzieci

Nykytyuk S, Klymnyuk S. Clinical and immunological status of children with Lyme disease. Health Prob Civil. 2021; 15(4): 253-254. https://doi.org/10.5114/hpc.2021.108379

Address for correspondence / Adres korespondencyjny: Svitlana Nykytyuk, Department of Children's Diseases and Pediatric Surgery, Ivan Horbachevsky Ternopil National Medical University, m. Voli 1, 46001 Ternopil, Ukraine, e-mail: svitlananyk@yahoo.com, phone: +380 352524492

ORCID: Svitlana Nykytyuk https://orcid.org/0000-0003-3146-9664, Sergiy Klymnyuk https://orcid.org/0000-0002-1308-3250

Copyright: (C) Pope John Paul II State School of Higher Education in Biała Podlaska, Svitlana Nykytyuk, Sergiy Klymnyuk. This is an Open Access journal, all articles are distributed under the terms of the Creative Commons Attribution-NonCommercial-ShareAlike 4.0 International (CC BY-NC-SA 4.0) License (http://creativecommons.org/licenses/by-nc-sa/4.0/), allowing third parties to copy and redistribute the material in any medium or format and to remix, transform, and build upon the material, provided the original work is properly cited and states its license. 
a person bitten by such a tick [5]. The serological examination of the patients was performed applying the ELISA method. The positive or intermediate results for the specific antibodies of at least one class were in IgM and / or IgG to the complex of B. burgdorferi s.l. and were detected approximately in $44.9 \%$ patients from the endemic zone.

Our analysis of the various diagnostic methods, PCR methods and immunofoermental (ELISA) methods will allow us to find answers to a number of important clinical, diagnostic, predictive and therapeutic questions, including the prognosis of future complications [6].

\section{References:}

1. Centers for Disease Control and Prevention. Reported cases of Lyme disease by year, United States, 19982019 [Internet]. Atlanta: Centers for Disease Control and Prevention; 2021 May 3 [cited 2021 Jul 13]. Available from: http://www.cdc.gov/lyme/stats/chartstables/casesbyyear.html

2. Rožic M, Lah LL, Ružic-Sabljic E. Lyme neuroborreliosis in children: etiology and comparison of clinical findings of Lyme neuroborreliosis caused by Borrelia garinii and Borrelia afzelii. The Pediatric Infectious Disease. 2019, 38(11): e279-e2843.

3. Nelson CA, Saha S, Kugeler KJ, Delorey MJ, Shankar MB, Hinckley A, et al. Incidence of cliniciandiagnosed Lyme disease, United States, 2005-2010. Emerging Infect. Dis. 2015; 21(9): 1625-1631. https://doi.org/10.3201/eid2109.150417

4. Kybicová K, Baštová K, Malý M. Detection of Borrelia burgdorferi sensu lato and Anaplasma phagocytophilum in questing ticks Ixodes ricinus from the Czech Republic. Ticks Tick. Borne. Dis. 2017; 8(4): $483-487$. https://doi.org/10.1016/j.ttbdis.2017.02.007

5. Levin ML, Fish D. Acquisition of coinfection and simultaneous transmission of borrelia burgdorferi and Ehrlichia phagocytophila by ixodes scapularis ticks. Infect. Immun. 2000; 684(4): 2183-2186. https://doi.org/10.1128/IAI.68.4.2183-2186.2000

6. Nykytyuk S, Pańczuk A, Shkilna M. Awareness of tick-borne bacterial infection in the students of nonmedical universities in Ternopil region (Western Ukraine). Health Prob Civil. 2017; 11(2): 99-102. https://doi.org/10.5114/hpc.2017.69026 